\title{
Post Transportation Analysis of Liver Biochemistry and Morphometric Colon in Broiler Supplemented by Probiotic
}

\author{
Roostita Lobo Balia", Diding Latipudin", Lovita Adriani ${ }^{\#}$, Lilis Suryaningsih ${ }^{\#}$, Andri Pratama ${ }^{\#}$, \\ Gemilang Lara Utama ${ }^{+}$ \\ ${ }^{\#}$ Faculty of Animal Husbandry, Universitas Padjadjaran, Sumedang, 40600, Indonesia \\ E-mail: *roostita@gmail.com
}

${ }^{+}$Faculty of Agricultural Industrial Technology, Universitas Padjadjaran, Sumedang, 40600, Indonesia

\begin{abstract}
The transportation process in the daytime will exposure heat stress on the broiler so that it leads to occur the alteration of metabolism in the broiler's body and damages some vital organs such as liver and colon. Therefore, it needs to be done a solution to solve those problems. One of those is the supplementation of probiotics. The research method was done by using Completely Randomized Design (CRD) 5 treatments and 4 replications T-0 (Control), T-1 Skimmed Milk + (Lactobacillus Plantarum + Lactobacillus acidophilus),T-2 Skimmed Milk + (Lactobacillus plantarum + Trichosporon beigelii), T-3 Skimmed Milk + (Lactobacillus plantarum + Cryptococcus humicolus), T-4 Skimmed Milk + (Trichosporon beigelii + Cryptococcus humicolus). The data analysis was done by using the ANOVA test. If the result was significant further tested by using an orthogonal test. Afterward, the Duncan test was used for testing the parameter of colon morphometric. The result shows that the probiotic supplementation has no significant result $(\mathbf{P}>0.05)$ on a level of protein and colon morphometric. However, it gives a positive effect if compared with control. Meanwhile, the probiotic supplementation gives a significant result $(\mathrm{P}<0.05)$ on a level of liver fat. The best treatment is $T-3$ because it has the lowest value of liver fat. Consequently, the probiotic supplementation can maintain broiler's performance at post transportation especially in handling heat stress.
\end{abstract}

Keywords — broiler; probiotic; liver biochemistry; morphometric colon; heat stress.

\section{INTRODUCTION}

Transportation is one of the crucial parts in the management of broiler farms because this activity will distribute broilers to consumers with the aim of seeds, enlargement, or slaughter for meat production. Generally, the farmer carries out the transportation activity in the day time so that it will be very risky in triggering the broiler to experience heat stress because they are exposed by sunlight from the environment. Heat stress is generated from the negative balance between the amount of energy flowing into the environment and the amount of heat energy produced by livestock. This imbalance could be caused by a combination of environmental factors such as sunlight, solar radiation, and humidity, and factor from livestock themselves such as metabolic rates and thermoregulatory mechanisms. Environmental stressors, such as heat stress, are very detrimental to farmers [1]-[3]. Moreover, the broiler is the type of livestock, which is more sensitive to the change of environment, especially heat stress. This is supported by the fact that modern poultry will produce body heat, due to its higher metabolic activity [4], [5].

The liver is one of the important organs for developing body-metabolic activity. When livestock occurs heat stress, the metabolism will be disrupted. Consequently, it will tear down an energy reserve such as glycogen in the liver and muscle. When the liver glycogen and muscle have been overhauled, the livestock's body will do gluconeogenesis process that is the formation of energy from noncarbohydrate components such as protein and fat for the homeostasis process. This will have an impact on decreasing the level of protein and fat because it will be used as energy to maintain the body's condition remaining stable. Heat stress also has an impact on colon morphometric because heat stress can decrease weight and colon length $22-25 \%$ and decrease the length of jejunum villi [6].

The probiotic supplementation is one of the alternatives, which can be used to anticipate stress on livestock due to transportation. Probiotics are a live microbe, and they are usually used as a feed additive and have a beneficial impact on health by increasing the microbe balance in the digestive 
tract. The probiotic mechanism in the digestive tract is neutralizing poison, suppressing the population of pathogenic bacteria as an anti-bacterial, and increasing the livestock immune system.

Some prior researchers have reported the utilization of probiotic as anticipation of stress on livestock. Utilization of probiotic Lactobacillus $s p$ in a broiler diet can control physiology response from the stress of transportation on broiler [7]. It is also said that utilization of probiotic ( $L$. sporogeneses, L. acidophilus, Saccharomyces cerevisiae) in poultry feed can increase the livestock immune system and decrease stress level after vaccination [8].

Nowadays, the research relates to the effect of probiotics on intestinal and liver organ is still not widely done. Thus, this study is conducted to determine the effect of probiotic during maintenance and to find out the best combination of starter probiotic, which will give the optimal result on liver biochemistry and colon morphometric. The condition of these organs will provide information about the performance of broilers during the transportation process in the day time.

\section{MATERIALS AND METHOD}

\section{A. Animal Preparation}

The research object was broiler strain cobb maintained in the starter phase to the finisher phase as many as 100 with a coefficient variation $<10 \%$. Broiler was entered into 20 units cage $70 \mathrm{~cm} \times 70 \mathrm{~cm}$ x $70 \mathrm{~cm}$ with every unit occupied 5 chicken. Probiotic used in this research consisted of 4 types, including Lactobacillus plantarum, Lactobacillus acidophilus, Trichosporon beigelii, and Cryptococcus humicolous with the dose given in the first week as much as $1 \mathrm{ml}$, the second week $2 \mathrm{ml}$, the third week $3 \mathrm{ml}$, and the fourth week $4 \mathrm{ml}$. Probiotic was dissolved into $50 \mathrm{ml}$ of skimmed milk.

\section{B. Method}

The research method was using Complete Randomized Design (CRD) with 5 treatments and 4 replications

- $\mathrm{T}-0$ = Control

- T-1=Skimmed Milk + (Lactobacillus plantarum + Lactobacillus acidhophillus)

- $\mathrm{T}-2=$ Skimmed Milk + (Lactobacillus plantarum + Trichoscoporon beigelii)

- $\mathrm{T}-3=$ Skimmed Milk + (Lactobacillus plantarum + Cryptococcus humicolus)

- $\mathrm{T}-4=$ Skimmed Milk + (Trichoscoporon beigelii + Cryptococcus humicolus).

The administration of probiotic was done in the afternoon (16:00-16:30) in the breeding phase. Probiotic was given in the form of a mixture of skimmed milk in which 30 grams of skim milk was dissolved in 1-liter water, and its feeding based on dosage every week. That mixture was divided into four bowls, and each bowl was filled with $100 \mathrm{ml}$ of water. Some broilers were transported for 6 hours in the last phase of breeding from Tanjungsari to Subang to measure the broiler resistance on stress. A total of 20 broiler carcass was taken the sample of colon and liver to be tested.

\section{Liver Protein}

The percentage of protein level could be calculated using the spectrophotometer method by the principle of creating a standard solution with the concentration known correctly. This was known its absorbance at each wavelength (530$570 \mathrm{~nm})$ by using a spectrophotometer. Furthermore, the total protein level could be known by dividing the absorbance result of the sample with the absorbance of standard and multiplied by the standard concentration. After that, the total protein could be converted into the crude protein by multiplying the total protein result with 6.25 so that the crude protein was obtained. The formulation to calculate total protein was shown below:

$$
\frac{A b s(\text { Assay })-A b s(\text { Specimen Elank) }}{\text { Abs }(\text { Standard })} x \text { Concentration }
$$

Total Protein $x 6.25$

\section{Liver Fat}

The percentage of the fat level could be calculated by using the Soxhlet extraction method with the principle that a fat solvent extracted fat. The solvent was evaporated and the fat could be weighed and calculated its percentage.

\section{E. Colon Morphometric}

The variable was the volume that was measured by using a cup $1 \mathrm{~L}$ and filled with distilled water. The measurement of volume used a method according to Archimedes's law. Afterward, the sample was dipped then calculated the difference in volume after dipping and before dipping. The measurement of length colon, rectum, and cecum was used rule while to obtain $\mathrm{pH}$ for each sample used $\mathrm{pH}$ meter.

\section{F. Data Analysis}

The data analysis can be done by using an analysis of variance. Then, if the result was significant, it could be tested further by the Duncan test for the variable of colon morphometric and orthogonal test for the variable of protein and fat.

\section{RESULTS AND DISCUSSIONS}

\section{A. The Effect of Probiotic on Liver Biochemistry}

Table (1) and Figure (1) presents the data regarding the level of fat and protein in each treatment.

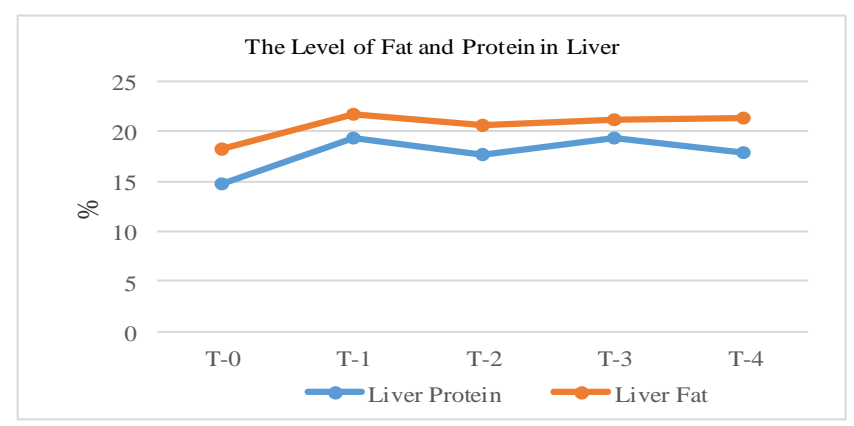

Fig. 1 Diagram of Protein and Liver 
TABLE I

THE EFFECT OF SUPPLEMENTATION PROBIOTIC ON LIVER BiocheMisTRY

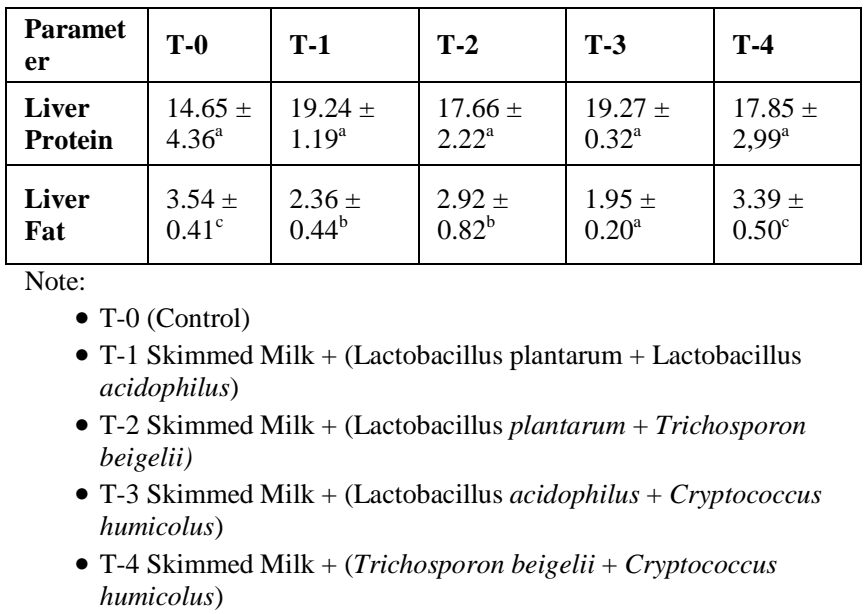

Based on Tabel 1 and Figure 1 can be seen that the highest protein $(19.27 \%)$ and the lowest fat $(1.95 \%)$ is observed in T-3 (C. humicolous + L. acidophilus) $19.27 \%$. Table 1 explains that $\mathrm{T}-3$ gives the optimal impact on the level of protein and the level of fat. The protein level at T-0 (control) shows the lowest results. This indicates that there is a high energy demand when the livestock is transported. The high energy requirement is intended to maintain the physiological condition of the body to remain stable (homeostatic), causing the activation of the catabolism pathways such as glycolysis, glycogenolysis, and gluconeogenesis. Mushawwir [9] has stated that the absence of energy intake during transportation causes an overhaul of the energy reserves in the form of glycogen at the liver and muscles. The alteration of glycogen into glucose is used as a new energy for the body's homeostatic process. Gluconeogenesis is the most obvious process occurring in the liver so that it has a direct impact on decreasing levels of liver protein.

Heat stress in the broiler can lead to an increase of gluconeogenesis in the liver because of increasing glucocorticoid hormone. Hillman, et al [10] has stated that glucocorticoids can trigger an increase of glucose formation in the body by increasing catabolism of proteins, glycogen, and lipids. The low protein can explain that corticotropinreleasing hormone $(\mathrm{CRH})$ will stimulate the pituitary anterior to secrete ACTH, then ACTH stimulates the adrenal cortex to produce glucocorticoid hormones. The high glucocorticoid hormone related to the low protein because gluconeogenesis in the liver increases.

The effect of each treatment can be known by using the ANOVA test. Based on the ANOVA test is obtained the result $\mathrm{F}_{\text {hit }}<\mathrm{F}_{\text {table. }}$. It means that probiotic supplementation has no significant result $(\mathrm{P}>0.05)$ in increasing liver protein. This indicates that the administration of probiotics with various combinations of bacteria and yeasts gives the same response. Nevertheless, overall the value of each treatment tends to increase and exceed the standard of protein level of broiler 16.92 [11].

The average protein, which is supplemented by probiotic, is relatively higher than protein standard so that it indicates that the giving of protein can balance the microflora in the digestive tract, improve the condition of the immune system, and utilize energy in the body being more efficient. As a result, there is no gluconeogenesis process in the liver, which affects a decrease in level protein. Further, it is enlightened by Fuller [12] that probiotic is a live microbial, which has a good impact on the animal by increasing the balance of microbial in the digestive tract. Probiotic can produce and increase the activity of protease enzyme so that the absorption of the nutrient will be more efficient and those nutrients will be utilized by broiler to growth. This is in line with Nahashon et al., [13] that probiotic produces various digestible enzymes such as protease. Consequently, the digestibility of nutrients will increase.

Winedar et al., [14] declare that feed fermented by microorganisms undergoes a simpler reshuffle so that the nutrient from the feed will be more natural to absorb. This is because the fermentation process, which produces protease enzyme, will break down protein to be an amino acid. Fermentation of organic compounds will express amino acid and saccharide in the form of the dissolved compound so that it will make absorption and the utilization of nutrients in the broiler body become better. This result indicates that probiotics can raise protein synthesis in the liver tissue.

The combination of yeast and bacterium works in synergy. Yeast like $C$ humicolous plays a role as a probiotic source that can support the lactic acid bacteria (LAB) growth ( $L$ acidophilus). It is due to the increase of the beneficialmicrobe population in the digestive tract so that the absorption nutrient in feed becomes more efficient. LAB is a proteolytic bacterium that has a function to digest protein. Surono [15] declares that the LAB will gradually hydrolysis protein involving protease enzymes to produce amino acids. This causes the protein level in the liver to increases.

The probiotic combination of LAB and yeast also has a function to decrease the fat level. Balia [16] declares that yeast acts like the bacterium that can create an acid condition in the host's body so that it can push pathogenic microorganisms out of their environment because they cannot stand in the acid condition. The acid condition (low $\mathrm{pH}$ ) makes the activity of the lipase enzyme limited, so that it causes a decrease in the fat level.

The ANOVA test can know the effect from each treatment. Based on the ANOVA test is obtained that $F_{\text {cal }}>$ $\mathrm{F}_{\text {tab }}$, this shows that the probiotic supplementation during maintenance is significantly different $(\mathrm{P}<0.05)$ in reducing liver fat. The average liver fat of broiler in this research is lower than the prior result. USDA (2014) has reported that the level of fat in broiler is $4.83 \%$. Wahju [17] reported that the level of fat of broiler is ranging between $3-5 \%$ from the fresh weight of the liver and $10-15 \%$ from the dry weight of the liver.

This decrease is caused by the influence of probiotic in the synthesis of fatty acid in the body. Santoso et al. [18] report that the administration of probiotics can decrease fat because probiotics can effectively decrease the activity of acetyl-coenzyme-A-carboxylase that plays a role in the rate of fatty acid synthesis. Ljung et al. [19] declare that probiotic can reduce fat in the body because it can produce a short-chain fatty acid in the digestive tract. A decline of fat synthesis in the digestive tract leads to fat, which is carried to the liver to be stored in the form of glycogen, which will decline. 
The result of the orthogonal contrast test shows that T-3 (C humicolous + Lacidophilus $)$ is the best treatment because it has the lowest value of liver fat and significantly different $(\mathrm{P}<0.05)$ to $\mathrm{T}-0, \mathrm{~T}-1, \mathrm{~T}-2$, and $\mathrm{T}-4$. Yeast plays a role as a microorganism which can increase the digestibility of high fibrous feed to be a volatile fatty acid [20]. The volatile fatty acid especially propionate, will inhibit the cholesterol synthesis in the liver within suppressing the activity of 3-hydroxy-3-methyl glutaryl Co-A reductase.

The ability of probiotic in stimulating the growth of LAB in the intestine also affects a decrease of fat. This is supported by Santoso et al., [18] that LAB such as Lactobacillus acidophilus can decrease the cholesterol level and triglyceride and increase the immune system. Probiotic can synthesize esterase enzyme and lipase enzyme to break down the ester bond, which is the link between fatty acid and glycerol. Scorve, et al. [21] have stated that the decrease of fatty acid in the liver is the main factor causing a decrease of triglyceride synthesis in the liver, which makes the concentration of triglyceride in serum reduces.

Yeast as a probiotic source can increase the amount of Lactic Acid Bacteria (LAB) which influences some of the digestive process and the fat absorption in the digestive tract. In the intestine, the $\mathrm{LAB}$ has a function to utilize energy which derives from a carbohydrate source to decrease the $\mathrm{pH}$ of the digestive tract to be 4.5. That condition makes the $\mathrm{pH}$ of the digestive tract be more acid. The acid environment makes the activity of lipase enzyme be limited because the lipase enzyme optimally works on $\mathrm{pH} 8.0$ [22], [23] so that the digestive of fat will reduce.

Another aspect that causes the level of fat decreases is the occurrence of lipolysis. Lipolysis is the breakdown of fat stored in fat cells involving the hydrolysis of triglycerides. Tortora and Anagnostakos [24] has stated that triglycerides in the liver will be broken down to be glycerol. Further, it will be converted to glucose through gluconeogenesis. Glycerol is converted to pyruvate through the glyceraldehyde-3-phosphate pathway and fatty acid are converted to acetyl CoA through the $\beta$-oxidation pathway which can then be involved in the Krebs cycle

\section{B. The Effect of Supplementation Probiotic on Colon Morphometric}

Table (2) and Figure (2), (3), and (4) are presented the data and illustration about the effect of supplementation probiotic on the colon. Based on Table 2 can be known that the lowest level of colon volume is T-4 (C. humicolous $+T$. beigelii) $6.75 \mathrm{ml}$ and the highest is T-0 (control) $8 \mathrm{ml}$. Then, the lowest of colon length is T-2 (L.plantarum + T.beigelii) $6.80 \mathrm{~cm}$.

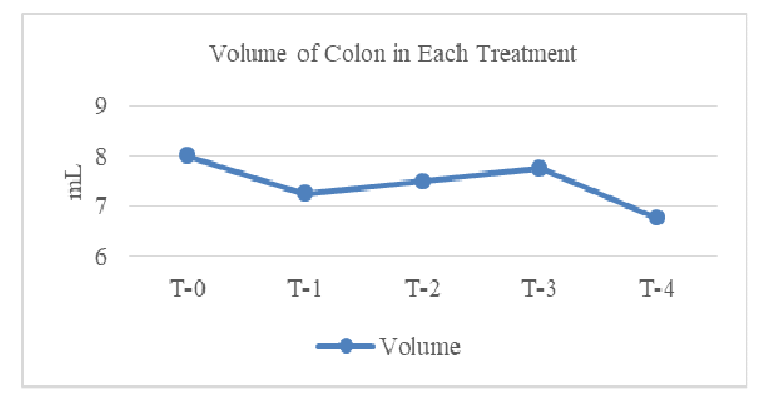

Fig 2. Diagram of Colon Volume

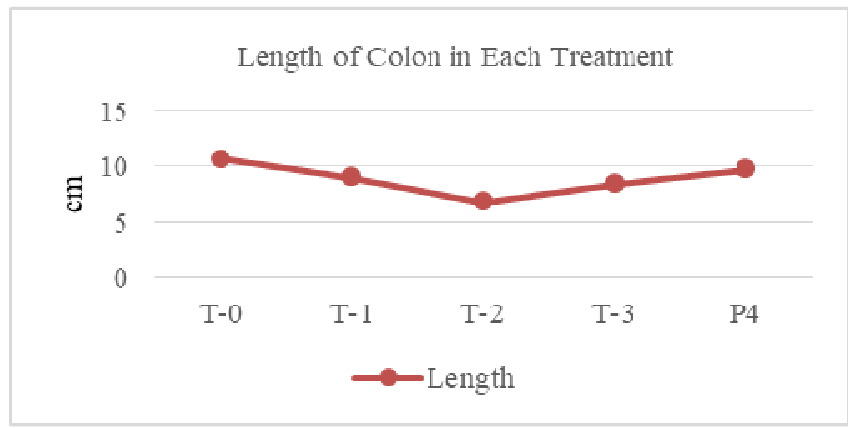

Fig 3. Diagram of Colon Length

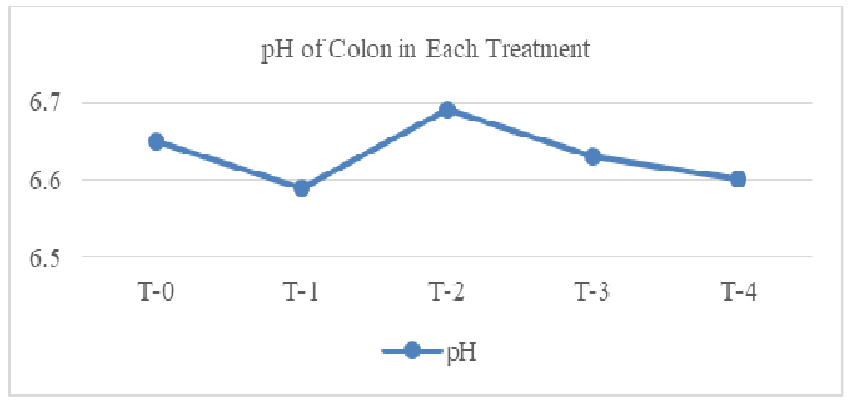

Fig 4. Diagram of Colon $\mathrm{pH}$

TABLE II

The COLON MORPhOMETRIC IN BROILER At Post Transportation

\begin{tabular}{|l|l|l|l|l|l|}
\hline Parameter & T-0 & T-1 & T-2 & T-3 & T-4 \\
\hline Volume & $8 \pm 0.82^{\mathrm{a}}$ & $\begin{array}{l}7,25 \pm \\
2 ., 06^{\mathrm{a}}\end{array}$ & $7.5 \pm 1.29^{\mathrm{a}}$ & $7.75 \pm 3.3^{\mathrm{a}}$ & $6.75 \pm 2.22^{\mathrm{a}}$ \\
\hline Length & $\begin{array}{l}10.63 \pm \\
1.60^{\mathrm{a}}\end{array}$ & $\begin{array}{l}9.00 \pm \\
1.41^{\mathrm{a}}\end{array}$ & $\begin{array}{l}6.80 \pm \\
1.65^{\mathrm{a}}\end{array}$ & $8.38 \pm 1.3^{\mathrm{a}}$ & $9.73 \pm 2.96^{\mathrm{a}}$ \\
\hline pH & $\begin{array}{l}6.65 \pm \\
0.21^{\mathrm{a}}\end{array}$ & $\begin{array}{l}6.59 \pm \\
0.39^{\mathrm{a}}\end{array}$ & $6.69 \pm 0.21^{\mathrm{a}}$ & $6.63 \pm 0.5^{\mathrm{a}}$ & $6.60 \pm 0.28^{\mathrm{a}}$ \\
Note: \\
• T-0 (Control) \\
• T-1 Skimmed Milk + (Lactobacillus plantarum + \\
- Lactobacillus acidophilus) \\
• T-2 Skimmed Milk + (Lactobacillus plantarum + \\
Trichosporon beigelii) \\
• T-3 Skimmed Milk + (Lactobacillus acidophilus + \\
Cryptococcus humicolus) \\
- T-4 Skimmed Milk + (Trichosporon beigelii + Cryptococcus \\
humicolus)
\end{tabular}

Meanwhile the lowest value of colon $\mathrm{pH}$ is $\mathrm{T}-1$ (L.plantarum + L.acidophilus ) 6.59. Based on the analysis variance is known that either volume, length, or $\mathrm{pH}$ does not give a significant result $(\mathrm{P}>0.05)$, but all the treatments give the positive effect to volume, length, and $\mathrm{pH}$ with proved no value that exceeds the control.

The volume of colon explains about the level of the feed digestibility in the broiler's body. The lower volume, the higher the feed digestibility. T-4 gives the optimal effect. This is due to the combination of yeast that can improve the intestinal microflora and increase feed efficiency. Pourabedin dan Zhao [25] declares that the yeast-cell wall can be as probiotic with efficiency to stimulate an immune system and improve the microflora in the intestine. The good intestinal microflora may increase the digestibility and the 
absorption of nutrients in the colon to be better. The lowcolon volume shows that the high absorption of nutrient so that waste product is lower and more comfortable to be issued. The low waste product indicates that much of the nutrients are absorbed, and the energy reserved in the body increases so that when the broiler is transported there is no stress because the energy for the metabolism process is sufficient. This is in line with Kompiang et al., [26] that probiotics can improve the digestive tract and increase the feed digestibility by suppressing the population of pathogenic bacteria in the digestive tract. Consequently, it supports the development of beneficial bacteria, which can help to absorb the nutrient.

If compared to control, all the probiotic combinations have a lower volume. T-0 (Control) has a higher volume so that it indicates that the digestibility at $\mathrm{T}-0$ is low. In the condition of heat stress, it will make broiler experience the imbalance microbial ecosystem in the gut and the immune system will decline [27]. By supplementing probiotics, those problems can be minimalized.

The average colon length in all treatments tends to be lower. This condition shows that the colon can digest faster. The shorter colon indicates that the absorption in the colon is higher than others and makes the distance of waste product becomes shorter. T-2 gives the optimal effect to the colon length because the combination of $\mathrm{LAB}$ and yeast is mutually beneficial. Yeast can support the process of LAB growth and will affect on increasing LAB. Eventually, it makes the condition of the intestine be more acid and inhibits the growth of the pathogenic microbe. Therefore, that condition can cause an increase in the digestibility rate and waste product becomes lower.

Table 2 shows that all treatments give the normal $\mathrm{pH}$ according to Mabelle et al. [28] which is around 6.20. it indicates that the probiotic combination can maintain the balance of $\mathrm{pH}$ in the intestine in a reasonable condition. T-1 gives the optimal effect because it is closer to the standard $\mathrm{pH}$ value. $\mathrm{LAB}$ generates lactic acid which can create the acid condition so that it can decrease the number of pathogenic bacteria. The lactic acid in the intestine makes the environment $\mathrm{pH}$ low, and another microbe especially pathogenic microbe, can not grow. This condition will make broiler in the transportation process be not occur stress.

\section{CONCLUSIONS}

The probiotic supplementation gives a significant result on the liver-fat level, and the best treatment is T-3 (C.humicolous + L.acidophilus). Although the probiotic supplementation does not provide a significant effect for the liver-protein and colon morphometric, it has given a positive impact like the increase of the liver protein at all treatments, provides the excellent condition for volume and length of the colon, and makes the $\mathrm{pH}$ colon close to the reasonable condition.

\section{ACKNOWLEDGMENT}

The author would like to be thankful to the rector of Universiti Padjadjaran, who has funded this research through the scheme of Academic Leadership Grant (ALG) for funding this research, and to Choirul Badriah, S.Pt., Lulu Izdihar Salsabila, S.Pt. for helping in finishing this paper.

\section{REFERENCES}

[1] Nienaber J.A., Hahn G.L. "Livestock production system management responses to thermal challenges", Int. J. Biometereol, vol. 52, pp. 49157, May. 2007.

[2] Nardone A., Ronchi B., Lacetera N., Ranieri M.S., Bernabucci U, "Effects of climate changes on animal production and sustainability of livestock systems", Livestock Sci, vol.130, pp. 57-69, May.2010

[3] Renaudeau D., Collin A., Yahav S., de Basilio V., Gourdine J.L., Collier R.J, "Adaptation to hot climate and strategies to alleviate heat stress in livestock production”, Animal, vol.6, pp.707-728, May.2012.

[4] Settar P., Yalcin S., Turkmut L., Ozkan S., Cahanar A, "Season by genotype interaction related to broiler growth rate and heat tolerance", Poult. Sci, vol.78, pp.1353-1358, Oct.1999.

[5] Deeb N., Cahaner A, "Genotype-by-environment interaction with broiler genotypes differing in growth rate. 3. Growth rate and water consumption of broiler progeny from weight-selected versus nonselected parents under normal and high ambient temperatures". Poult. Sci, vol.81, pp.293-301, Mar. 2002.

[6] Bonnet, S., P. A. Geraert, M. Lessire, B. Carre, and S. Guillaumin. "Effec of high ambient temperature on feed digestibility in broilers", Institut National de la Recherche Agronomique, 37380 Nouzilly. France, vol. 2, pp. 857-863, June.1997.

[7] Ghareeb, K., W.A. Awad, S. Nitsch, S. Abdel-Raheem dan J. Bohm., "Effects of Transportation on Stress and Fear Responses of Growing Broilers Supplemented with Prebiotic or Probiotic", International Journal of Poultry Science, vol .7, pp. 678-685, July.2008.

[8] Dhama, K., V. Verma, K.P.M. Sawant, R. Tiwari, R.K. Vaid and R.S. Chauhan, "Applications of Probiotics in Poultry: Enhancing Immunity and Beneficial Effects on Production Performances and Health - A Review", Journal of Immunology and Immunophatology, vol.13, pp. 1-19, January.2011.

[9] Mushawwir, A, Biokimia Nutrisi, Fakultas Peternakan Universitas Padjadjaran, Sumedang-Indonesia, 2014.

[10] Hillman, P.E., N.R. Scot., Tienhoven., "Physiological, Responses and Adaptations to Hot and Cold Environment". Stress Physiology in Livestock, vol.3, Poultry. Florida: CRC Press, pp 1-71.

[11] "Basic Report", National Nutrient Database for Standard Reference Releases, United States Departement for Agriculture, USA.

[12] Fuller R, Probiotics: The Scientific Basis. Chapman and Hall, London-England, 1992.

[13] Nahashon, S.N., H.S. Nakaue dan L.W. Mirosh, "Performance of Single Comb White Leghorn Fed a Diet Supplemented with a Live Microbial During the Growth and Egg Laying Phases", Anim. Feed Sci. Techol, vol.57, pp. 25-38, January.1996.

[14] Winendar, N., S. Listyawati, and Sutarno. "Daya Cerna Protein Pakan, Kandungan Protein Daging dan Pertambahan Berat Badan Ayam Broiler setelah Pemberian Pakan yang Difermentasi dengan Effective Microorganisms-4 (EM-4)" . Universitas Sebelas Maret, Surakarta, 2004.

[15] Surono, I.S, Probiotik Susu Fermentasi dan Kesehatan, YAPMMI. TRICK, Jakarta, Indonesia, 2004.

[16] Balia, R. L, "Potensi dan Prospek Yeast (Khamir) dalam Meningkatkan Diversifikasi Pangan di Indonesia", Departemen Pendidikan Nasional Universitas Padjadjaran, Bandung. 2004.

[17] Wahju, J, Ilmu Nutrisi Unggas. Gadjah Mada University Press, Yogyakarta-Indonesia, 1997.

[18] Santoso, U., K. Tanaka, and S. Ohtani, "Effect of dried bacillus subtilis culture on growth, body composition and hepatic lipogenic enzyme activity in female broiler chicken", Br. J. Nutr, vol. 74, pp.523-529, Oct.1995.

[19] Ljungh A., W. Torkel, "Lactiz Acid Bacteria ad Probiotic", Curr.Issue Intestinal Microbiol, vol.7, pp. 73- 90. 2005.

[20] Wallace, R.J. and C.J. Newbold, "Rumen Fermentation and Its Manipulation the Development of Yeast Cultures as Feed Additives", Allech's Asia Pacific Lecture Tour, pp. 149-168, 1993.

[21] Scorve, J., A. Al-Shurbaji, D. Asiedu, I. Bjorkhem, L. Berglund dan R.K. Berge, "On the Mechanism of the Hypolipidemic Effect of Sulfur-Substituted Hexadecanedionic Acid (3-Thiadicarboxylic Acid) in Normolipidemic Rats". J Lipid Res, vol. 34, pp. 1117-1185, August.1993. 
[22] Djojosoebagio, S., Fisiologi Kelenjar Endokrin Volume II. Departemen Pendidikan dan Kebudayaan. Dirjen. Dikti. Pusat Antar Universitas Ilmu Hayat. IPB, Bogor.1990.

[23] Piliang, W.G and S. Djojosoebagio Al Haj, Fisiologi Nutrisi Volume II. IPB Press, Bogor Indonesia, 2006.

[24] Tortora, G.J. and N.P. Anagnostakos, Principles of Anatomy and Physiology, 6th ed. Harper and Row Publ, New York-America, 1990.

[25] Pourabedin M, Zhao X, "Prebiotics and gut microbiota in chickens", FEMS MicrobiolLett, vol 36, Aug. 2015.
[26] Kompiang, I.P, "Pengaruh ragi Saccharomyces cerevisiae dan ragi laut sebagai pakan imbuhan probiotik terhadap kinerja ungags", J. Ilmu Ternak dan Veteriner, vol.7, pp. 18-21.2002.

[27] Jin, L. Z., Y. W. Ho, M. A. Ali, N. Abdullah, and S. Jalaluddin, , "Probiotics in poultry: modes of action", World's Poultry Science Journal, Vol.53, pp. 351-368, December.1997.

[28] Mambelebele, M, O.J.Alabi, J.W. Ngambi, D.Norris, M.M.Ginindza, " Comparison of Gastrointestinal Tract and $\mathrm{pH}$ value of Digestive Organs of Ross 308 Broiler and Indigenous Venda Chickens Fed The Same Diet", Asian Journal of Animal Science and Veterinary Advances, vol.9, pp. 71-76, 2014. 